\title{
Short-term effects of mating on the accessory sex glands of the male rat
}

\author{
K. Purvis*, E. Haug†, Y. Thomassen‡, B. Mevåg§ and H. Rui* \\ *Institute of Pathology, The National Hospital; †Hormone Laboratory, Aker Hospital; $\ddagger$ Institute of \\ Occupational Health; and §Institute of Forensic Medicine, The National Hospital, Oslo, Norway
}

\begin{abstract}
Summary. Mating in the rat was associated with a significant reduction in the tissue concentrations of the presumptive secretory products of the male accessory sex glands: prostatein and the amines, putrescine, spermidine and spermine (ventral prostate lobe), zinc (lateral prostate lobe) and fructose (coagulating gland). The amount of secretory product discharged and the time taken to restore precopulatory levels differed for the different lobes.

Within 12-24 h of the mating period, the activity of ornithine decarboxylase and cytosolic oestrogen binding in the ventral prostate lobe underwent a transient increase which lasted 2-3 days. No change was observed in prolactin binding.

Circulating testosterone concentrations were significantly elevated above control values $12 \mathrm{~h}$ after the start of mating but were significantly lower than control values at $24 \mathrm{~h}$. A gradual recovery to concentrations in controls occurred over the next 2-3 days. None of these changes could be explained by alterations in gonadotrophin or prolactin release.
\end{abstract}

\section{Introduction}

Much information has accumulated over the years on the hormonal control and secretory function of the accessory sex glands, but few studies have attempted to determine the relevance of these findings in relation to the biochemistry of these glands under the more physiological conditions of mating and ejaculation. The purpose of the present study was to monitor alterations in various secretory characteristics and in certain aspects of cellular biochemistry in the accessory sex glands of the rat at various times after an intense period of sexual activity. Attempts were made to correlate any of the changes observed with fluctuations in the concentrations of plasma testosterone and gonadotrophins.

\section{Materials and Methods}

Mating study. Fifteen female Sprague-Dawley rats (70 days of age) were brought into oestrus by two daily i.m. injections of $100 \mu \mathrm{g}$ oestradiol valerate in peanut oil $(0.1 \mathrm{ml})$ and a single i.m. injection of $1.0 \mathrm{mg}$ progesterone in the same vehicle $(0.25 \mathrm{ml}), 6 \mathrm{~h}$ before the planned time of mating (Purvis \& Haynes, 1972). Thirty adult males (125 days of age) of the same strain were divided into 2 equal groups and individuals from the first group were placed together with an oestrous female in separate cages. After $12 \mathrm{~h}(21: 00-09: 00 \mathrm{~h})$ the males of the first group were removed. The females were grouped together and given a further injection of oestradiol valerate. The males of the second group were then individually exposed to the females for the same length of time the following night (21:00-09:00 h). All males had been randomly allocated to 6 groups before mating and were killed immediately at the end of the mating period or $1,2,3,4$ and 6 days after the start. 
Control groups of unmated animals were killed in parallel. During the mating period, the control rats were also separated in groups of two in new cages for $12 \mathrm{~h}$. All male rats, including controls, were given sexual experience by contact with oestrous females for $6 \mathrm{~h} 1$ week before the start of the study.

Blood was collected after decapitation and the ventral and lateral lobes of the prostate and the coagulating glands were dissected free and frozen in an alcohol-solid $\mathrm{CO}_{2}$ bath. They were subsequently stored at $-70^{\circ} \mathrm{C}$ until the day of assay. The seminal vesicles were ligated at their base, removed and weighed, and then reweighed after extrusion of the secretion to compute the volume of secretory fluid present.

Assay of plasma hormones. LH, FSH, prolactin and testosterone were determined using radioimmunoassay procedures described elsewhere (Purvis, Illius \& Haynes, 1974; Haug \& Gautvik, 1976; Purvis, Haug, Clausen, Naess \& Hansson, 1977). The sensitivities and the withinassay coefficients of variation were $200 \mathrm{pg}$ and $<7 \%$ for $\mathrm{LH}, \mathrm{FSH}$ and prolactin, and $12.5 \mathrm{pg}$ and $<6 \%$ for testosterone.

Assay of glandular secretory products. The techniques of measuring ventral lobe prostatein and the prostate amines putrescine, spermidine, spermine, lateral lobe zinc and coagulating gland fructose have all been published previously (Lea, Petrusz \& French, 1979; Rui, Haug, Mevåg, Thomassen \& Purvis, 1985b). All assays were carried out in individual organs. Within-assay coefficients of variation were $<8 \%,<4 \%,<5 \%$ and $<10 \%$ for prostatein, the polyamines, zinc and fructose determinations respectively. The limits of assay sensitivity for the polyamines, zinc and fructose assays were $10 \mathrm{nmol} / \mathrm{g}, 1.8 \mu \mathrm{mol} / \mathrm{g}$ and $0.4 \mu \mathrm{mol} / \mathrm{g}$ tissue weight, respectively.

Assay of prolactin and oestrogen binding. Prolactin binding to ventral prostate membranes and ventral lobe cytosolic binding were assessed on pools of material by using previously reported techniques (Charreau et al., 1977; Purvis, Mørkås, Rui \& Attramadal, 1985; Rui et al., 1985b). The within-assay coefficients of variation were $<5 \%$ and $<3 \%$ for prolactin and oestrogen binding, respectively.

Assay of ornithine decarboxylase (EC 3.5.3.1) activity. Individual lobes of ventral prostates

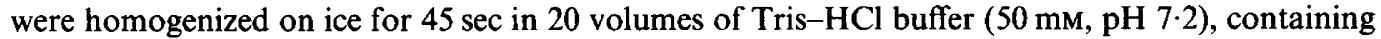
5 mM-dithiothreitol, 0.1 mM-EDTA and 0.2 mM-pyridoxal phosphate (Sigma Chemical Co., St Louis, MO, U.S.A.) followed by centrifugation at $20000 \mathrm{~g}$ for $30 \mathrm{~min}$. The supernatant ( $1 \mathrm{ml}$ ) was transferred to $25 \mathrm{ml}$ flasks and subjected to enzyme assay. The reaction was started by addition of $1 \mathrm{ml}$ buffer containing $200 \mathrm{nmol} \mathrm{L}$-ornithine and $2 \mathrm{nmol} \mathrm{DL}-\left[{ }^{14} \mathrm{C}\right]$ ornithine (sp. act. $57 \mu \mathrm{Ci} / \mathrm{mmol}$; Amersham, U.K.).

The flasks were closed with rubber stoppers, and incubated in a shaking water bath at $37^{\circ} \mathrm{C}$ for $30 \mathrm{~min}$, and the reaction was terminated by injection of $1 \mathrm{ml} 2 \mathrm{M}$-citric acid through the rubber stopper. It was allowed to stand for a further 60 min to ensure the complete release of ${ }^{14} \mathrm{CO}_{2}$ which was absorbed by a Whatman 17 filter strip containing $50 \mu$ l ethanolamine (Sigma) diluted to $33 \%$ in ethylene glycol. The filter strip was placed in a plastic well held by the rubber stopper. After incubation the papers was transferred to vials containing $10 \mathrm{ml}$ scintillation fluid and counted for ${ }^{14} \mathrm{C}$ activity. Validation of the assay for ventral lobe tissue and optimalization of incubation conditions are reported elsewhere (Rui, Brekke, Mørkăs \& Purvis, 1986). Within-assay variation was $<10 \%$ and the limit of assay sensitivity was $75 \mathrm{fmol} / \mathrm{min} / \mathrm{mg}$ protein.

Measurement of protein. Protein in cytosols and membranes was measured using the method of Lowry, Rosebrough, Farr \& Randall (1951) with bovine serum albumin as reference standard. 


\section{Results}

Effects of mating on the presumptive secretory products of the accessory sex glands

In all figures the data from the mated animals on the different occasions are joined by a continuous line. Although histograms are strictly more correct the data are presented this way for the sake of clarity.

Figure 1 shows that after a 12-h mating period the amount of seminal vesicle fluid, the prostate concentrations of prostatein and zinc and the coagulating gland fructose concentrations were all significantly decreased below control levels $(P<0.001, P<0.02, P<0.05$ and $P<0.001$, respectively). This decrease constituted $75 \%, 34 \%, 50 \%$ and $58 \%$ of the control value, respectively. Normal levels were restored within 1-2 days for prostatein, 3 days for zinc and fructose, and 4 days for vesicular secretion. Although prostatein, fructose and vesicular fluid gradually recovered to precopulatory levels, the concentrations of zinc remained depressed at the same level for the first 2 days and then rapidly increased to within control levels on the 3rd day. By 6 days after mating the vesicular content of secretion had risen to a value which was significantly higher than in the controls $(P<0.05)$.

Figure 2 demonstrates how the above alterations compared to changes in the concentrations of soluble proteins in the respective glands. Different glands exhibited differences in the extent and the direction to which their tissue protein content was affected by mating. Protein concentrations in the ventral lobes were not significantly altered by mating whereas the proteins of the lateral lobe and coagulating gland cytosols were significantly altered but in opposite directions. Although the greatest loss in the classical secretory products of the accessory sex glands was observed at the end of the mating period, alterations in the tissue protein concentrations occurred after a delay. The
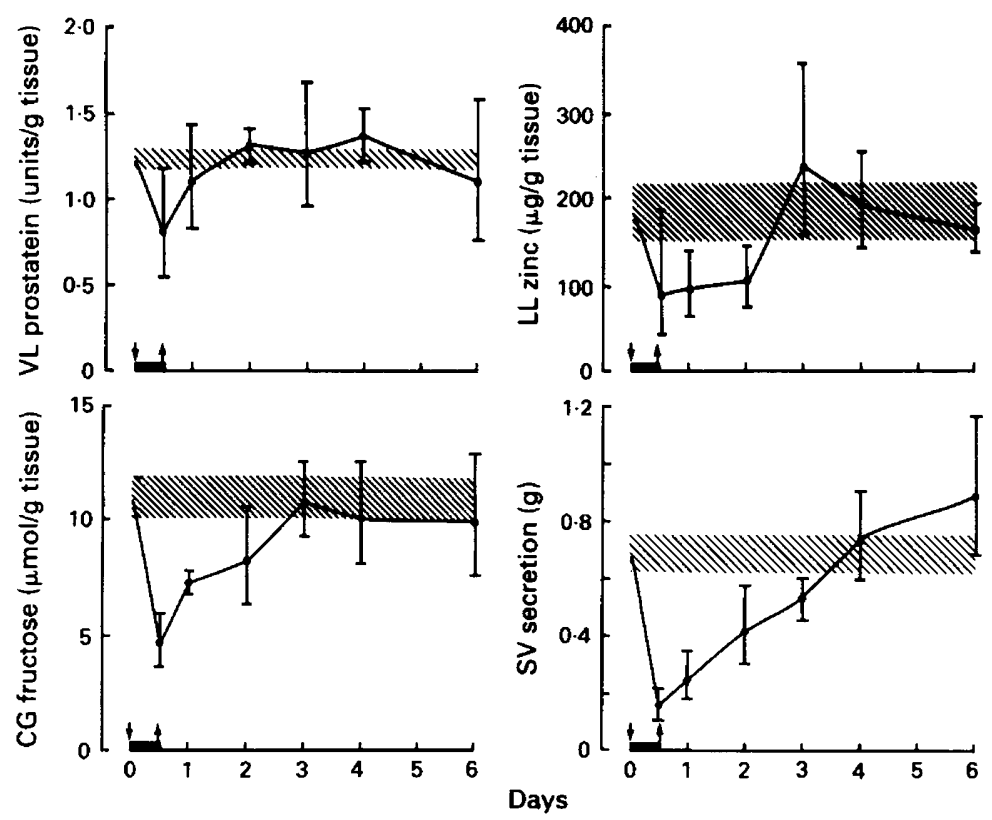

Fig. 1. Concentrations of ventral lobe (VL) prostatein, lateral lobe (LL) zinc, and coagulating gland (CG) fructose and the weight of seminal vesicle (SV) secretion in male rats killed at various times ( $12 \mathrm{~h}-6$ days) after exposure to oestrous females for $12 \mathrm{~h}$. The arrows delineate the mating period. Vertical bars represent the $95 \%$ confidence limits of geometric means. The hatched areas are the $95 \%$ confidence limits of the pooled data from control animals killed on the same occasions. 


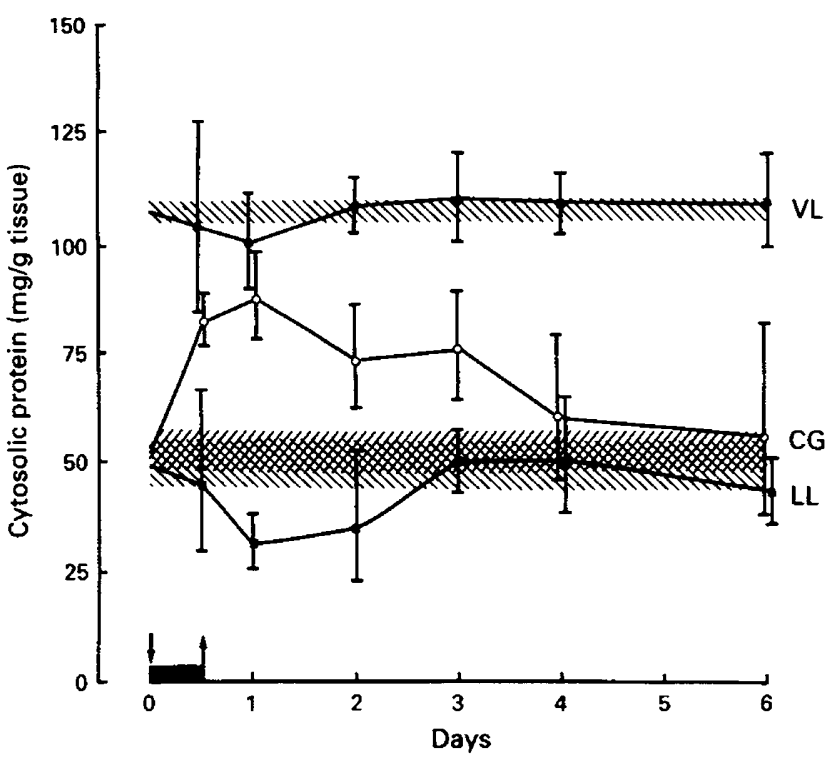

Fig. 2. Concentrations of cytosolic protein in the ventral lobes (VL), lateral lobes (LL) and coagulating glands (CG) of male rats killed at various times after exposure to oestrous females for $12 \mathrm{~h}$. The arrows delineate the mating period. Vertical bars represent the $95 \%$ confidence limits of geometric means. The hatched areas are the $95 \%$ confidence limits of the pooled data from control animals killed on the same occasions. $95 \%$ confidence limits for control CG; 95\% confidence limits for control LL.

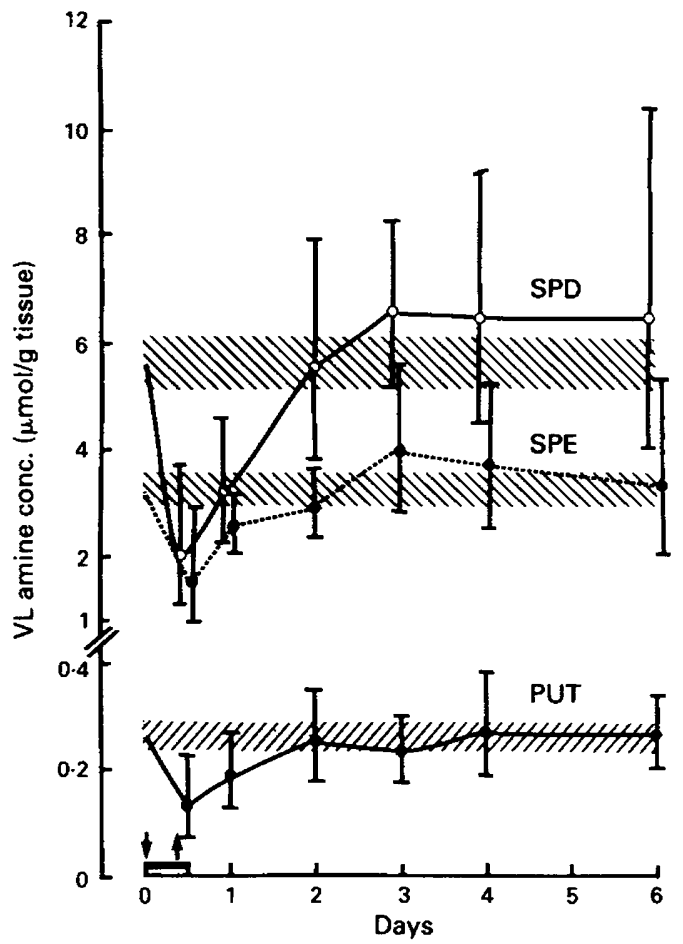

Fig. 3. Concentrations of putrescine (PUT), spermidine (SPD) and spermine (SPE) in the ventral lobes of male rats killed at various times after exposure to oestrous females for $12 \mathrm{~h}$. The arrows delineate the mating period. Vertical bars represent the $95 \%$ confidence limits of geometric means. The hatched areas are the $95 \%$ confidence limits of the pooled data from control animals killed on the same occasions. 
lowest protein concentrations in the lateral lobe were observed $12 \mathrm{~h}$ after the nadir in the zinc concentrations in the same gland. Protein concentrations at $12 \mathrm{~h}$ were not affected but were significantly different from control levels at $24 \mathrm{~h}(P<0.001)$. Similarly, the significant elevation observed in protein concentrations in the coagulating gland was maximal $(P<0.001) 12 \mathrm{~h}$ after the nadir in fructose concentrations. Because of these alterations in protein concentration, the concentrations of the various secretory components were expressed per gram wet weight and not per unit soluble protein.

Alterations in the ventral lobe concentrations of putrescine and the polyamines are shown in Fig. 3. A nadir in the concentration of all amines was observed immediately at the end of the mating period $(P<0.001$ for spermidine and $P<0.05$ for putrescine and spermine) and these had all recovered to within control limits by 2 days. Although putrescine and spermine were decreased to about $50 \%$ of their control levels at $12 \mathrm{~h}$, the ventral lobe concentration of spermidine was decreased by $64 \%$.

Effects of mating on prolactin and oestrogen binding and ornithine decarboxylase activity in the ventral lobe

By 2 days after the onset of mating the activity of ornithine decarboxylase in the ventral lobe was significantly higher than control levels $(P<0.001)$. By the 3rd day this difference had disappeared (Fig. 4). Because the oestrogen binding data were obtained from pools it was not
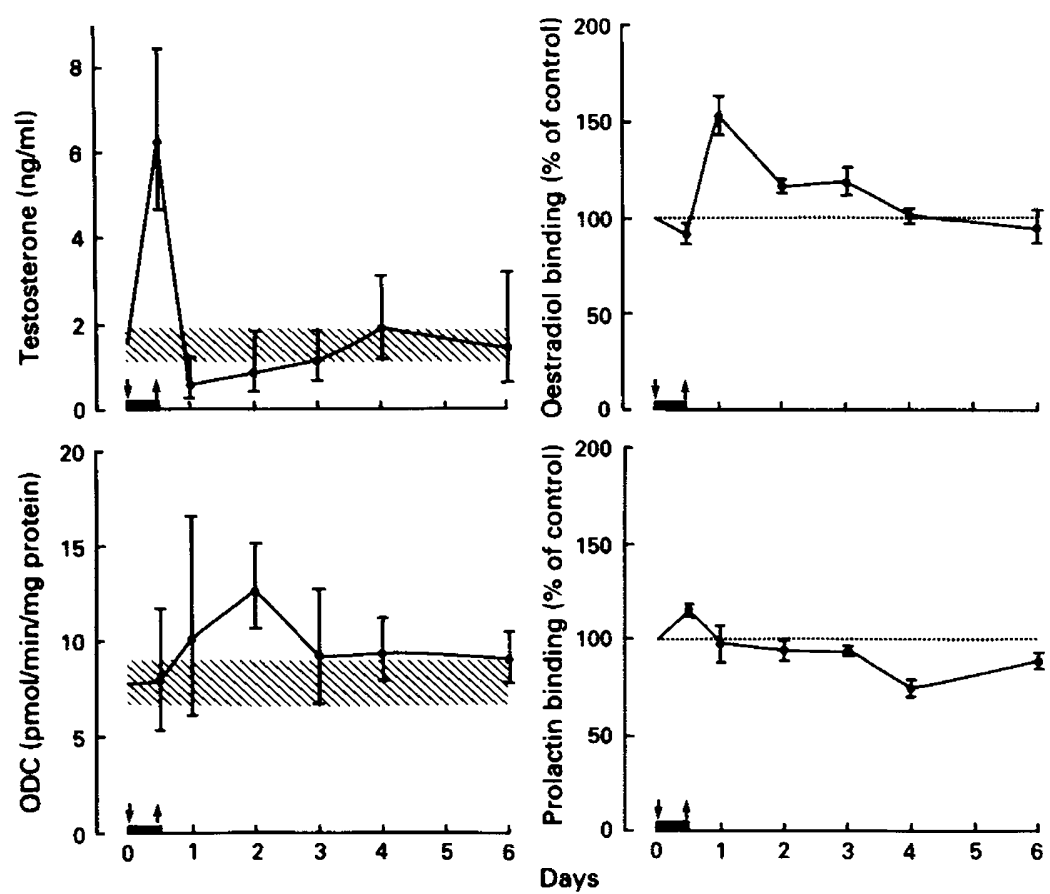

Fig. 4. Plasma testosterone and the activities of ornithine decarboxylase (ODC), and specific oestradiol and prolactin binding in the ventral lobes of male rats killed at various times after exposure to oestrous females for $12 \mathrm{~h}$. The arrows delineate the mating period. In the case of testosterone and ODC activity the vertical bars represent the $95 \%$ confidence limits of geometric means. The hatched areas are the $95 \%$ confidence limits of the pooled data from control animals killed on the same occasions. Vertical bars for oestradiol and prolactin binding represent s.d. of triplicate determinations on pools of tissue derived from 5 rats. 
Table 1. Plasma concentrations (geometric mean and 95\% confidence limits) of luteinizing (LH), follicle-stimulating hormone (FSH) and prolactin in male rats at various times after exposure to oestrous females

\begin{tabular}{llcccccc}
\hline & & \multicolumn{7}{c}{ Time (days) } \\
\cline { 3 - 7 } & & $0 \cdot 5$ & 1 & 2 & 3 & 4 & 6 \\
\hline LH & & 66 & 59 & 73 & 47 & 48 & 57 \\
& Control & $(44-99)$ & $(47-73)$ & $(52-104)$ & $(33-66)$ & $(35-36)$ & $(43-76)$ \\
& & 61 & 60 & 54 & 57 & 56 & 74 \\
FSH & Mated & $(44-85)$ & $(43-84)$ & $(87-33)$ & $(41-81)$ & $(37-83)$ & $(70-77)$ \\
$(\mathrm{ng} / \mathrm{ml})$ & & 380 & 480 & 470 & 430 & 290 & 360 \\
& Control & $(260-550)$ & $(360-630)$ & $(430-510)$ & $(210-890)$ & $(220-380)$ & $(200-630)$ \\
& & 420 & 450 & 350 & 430 & 390 & 360 \\
Prolactin & Mated & $(340-520)$ & $(340-610)$ & $(230-530)$ & $(310-590)$ & $(310-500)$ & $(200-670)$ \\
& & 44 & 73 & 59 & 85 & 62 & 50 \\
& Control & $(26-73)$ & $(50-106)$ & $(33-106)$ & $(59-122)$ & $(44-87)$ & $(37-67)$ \\
& & 35 & 81 & 49 & 63 & 42 & 54 \\
& Mated & $(24-51)$ & $(62-104)$ & $(32-77)$ & $(42-93)$ & $(20-88)$ & $(41-72)$ \\
\hline
\end{tabular}

possible to carry out a statistical analysis. However, when expressed as a percentage of the control mean, the cytosolic binding in mated animals appeared to be stimulated more than $50 \%$ by $24 \mathrm{~h}$ after the onset of mating, with a gradual return to control levels over the subsequent 3 days. No major alterations in prolactin binding to ventral lobe membranes could be demonstrated (Fig. 4).

\section{Effects of mating on circulating plasma hormones}

Plasma testosterone concentration was markedly stimulated above control levels $(P<0.001)$ $12 \mathrm{~h}$ after the onset of mating (Fig. 4) but was significantly decreased below normal levels $(P<0.05)$ at $24 \mathrm{~h}$. These values were then restored to normal over the next 1 or 2 days. No significant alterations were observed in plasma LH, FSH or prolactin concentrations throughout the observation period (Table 1).

\section{Discussion}

As could be anticipated, copulation in the rat was associated with a transient decrease in the glandular concentrations of six of the presumptive secretory products of the rat accessory sex organs: prostatein, zinc, fructose and the amines putrescine, spermidine and spermine. A marked reduction in the volume of secretion present in the seminal vesicles was also recorded. Generally it took 3 and 4 days before the tissue levels of these various components could be restored to precopulatory levels, presumably related to differences in the discharge of their tissue contents. It also takes between 3 and 4 days before the alterations that occur in seminal characteristics of men after a period of frequent ejaculation are returned to normal (Rui, Gerhardt, Mevåg, Thomassen \& Purvis, 1984). When expressed as a fraction of the precopulatory level, the ventral lobe of the prostate lost relatively little of its glandular content of prostatein, which was then rapidly restored within 1-2 days of the copulatory period. In contrast, the coagulating gland and seminal vesicle apparently discharged a greater fraction of their contents and took 1 and 2 days more to recover their normal state. The polyamines, spermidine and spermine, which are also secretory products of the ventral lobe, were lost to much greater extents than prostatein, indicating that the extracellular pool of products destined for release at ejaculation may differ even when they originate from the 
same tissue. Although the rate of recovery of the various secretions generally followed a gradual and regular time course from a nadir immediately after the end of the $12 \mathrm{~h}$ mating period, the pattern in the lateral lobe was less uniform. For the first 2 days no change in the post-copulatory content of zinc could be detected whilst between the 2 nd and 3rd day, a sudden accumulation of zinc occurred. This inability of the lateral lobe to compensate rapidly for reductions in its zinc content has also been noted previously in hypoprolactinaemic rats given a single dose of prolactin (Rui et al., 1985b).

The polyamines are present in all somatic cells (Cohen, 1978) and act as mediators of RNA and protein synthesis (Russell, 1980). In the prostate they also constitute secretory products which are released in large quantities (Williams-Ashman \& Lockwood, 1970). Thus alterations in their tissue concentrations represent the sum of their loss in the secretion and any alterations associated with their role as mediators of intracellular biochemical reactions. Whereas putrescine and spermine were lost from the ventral lobe to a comparable extent, the changes in the spermidine concentration indicated that this amine was preferentially secreted by the ventral lobe.

The alterations observed in ventral lobe oestrogen binding and ornithine decarboxylase activity are interesting because (1) they occurred under physiological conditions and (2) they indicate that oestrogens and ornithine decarboxylase have an important role to play in the modulation of prostate function. As mentioned above, the polyamines are mediators of RNA and protein synthesis, and oestrogens have been implicated.in the control of prostatic function and in the aetiology of prostatic disease for many years (Wilson, 1980). The cause of this relatively rapid increase in oestrogen binding and the slower activation of ornithine decarboxylase is probably linked to the transient elevation in circulating testosterone concentrations which occurred during mating. This increase in androgen levels associated with copulation has been observed in a number of species, including rat (Purvis \& Haynes, 1974), monkey (Rose, Gordan \& Berstein, 1972), rabbit (Saginor \& Horton, 1968), bull (Katongole, Naftolin \& Short, 1971) and man (Fox, Ismail, Love, Kirkham \& Loraine, 1972), although its implications have rarely been discussed or investigated. Certainly a relatively rapid activation of ornithine decarboxylase by androgen has been shown to occur in the prostate by others (Pegg, Lockwood \& Williams-Ashman, 1970). Since this enzyme is regarded as a rate-limiting step in polyamine biosynthesis, it may constitute a means by which androgen can exert a relatively rapid and efficient control over protein synthesis to restore depleted reserves of secretory products.

Under normal conditions, oestrogen binding in the rat prostate follows a circadian rhythm with peaks and troughs occurring about $3 \mathrm{~h}$ after excursions in circulating testosterone, suggesting a causal relationship (Rui et al., 1985a). Moreover, a transient elevation in plasma testosterone induced by a single injection of hCG is closely followed by a significant increase in prostatic oestrogen binding (unpublished results). This and the evidence of the present study suggest that under physiological conditions there is a dynamic equilibrium between androgen and prostatic oestrogen receptors, although its significance and the details of its mechanisms have still to be elucidated.

The cause of the increase in plasma testosterone has been assumed to be due to an elevated pituitary secretion of LH mediated by central nervous influences (Saginor \& Horton, 1968; Katongole et al., 1971). However, in the present study no clear alteration in the gonadotrophins occurred which could account for such an increase. One possibility is that these changes had occurred in the first $12 \mathrm{~h}$ before the first blood sample was taken.

Studies on the manifestations of copulation in the rat, which appear to involve a physiological stimulation of the rat Leydig cell, may constitute a model by which the relevance of theoretical control mechanisms can be evaluated. In addition, the same model may serve as a useful means of judging the validity of proposed androgen effects on the accessory sex glands which have been derived from experiments using unphysiological doses of hormone in unnatural conditions.

We thank Dr O. Lea, Haukeland Hospital, Bergen, for the gift of prostatein antiserum and Inger Brekke and Lise Mørkås for skilful technical help. This study was supported by Norsk 
Forening til Kreftens Bekjempelse and Landsforeningen mot Kreft. H.R. is in receipt of a NAVF scholarship.

\section{References}

Cohen, S.S. (1978) The functions of the polyamines. In Advances in Polyamine Research, Vol. 1, pp. [-10. Ed. R. A. Campbell. Raven Press, New York.

Charreau, E.H., Attramadal, A., Torjesen, P.A., Purvis, K., Calandra, R. \& Hansson, V. (1977) Prolactin binding in rat testis: specific receptors in interstitial cells. Molec. cell. Endocr. 6, 303-307.

Fox, C.A., Ismail, A.A.A., Love, D.N., Kirkham, K.E. \& Loraine, J.A. (1972) Studies on the relationship between plasma testosterone levels and human sexual activity. J. Endocr. 52, 51-58.

Haug, E. \& Gautvik, K.M. (1976) Effects of sex steroids on prolactin secreting rat pituitary cells in culture. Endocrinology 99, 1482-1489.

Katongole, C.B., Naftolin, F. \& Short, R.V. (1971) Relationship between blood levels of luteinizing hormone and testosterone in bulls and the effects of social stimulation. J. Endocr. 50, 457-466.

Lea, O.A., Petrusz, P. \& French, F.S. (1979) Prostatein: a major secretory protein of the rat ventral prostate. $J$. biol. Chem. 254, 6196-6202.

Lowry, O.M., Rosebrough, N.J., Farr, A.L. \& Randall, R.J. (1951) Protein measurement with the Folin phenol reagent. J. biol. Chem. 193, 265-275.

Pegg, A.E., Lockwood, D.H. \& Williams-Ashman, H.G. (1970) Concentrations of putrescine and the polyamines and their enzymic synthesis during androgeninduced prostatic growth. Biochem. J. 117, 17-31.

Purvis, K. \& Haynes, N.B. (1972) The effect of female rat proximity on the reproductive system of male rats. Physiol. Behav. 9, 401-407.

Purvis, K., Illius, A.W. \& Haynes, N.B. (1974) Plasma testosterone concentrations in the ram. J. Endocr. 61, 241-253.

Purvis, K., Haug, E., Clausen, O.P.F., Naess, O. \& Hansson, V. (1977) Endocrine status of the testicular feminized male (tfm) rat. Molec. Cell. Endocr. 8, 73-80.
Purvis, K., Mørkås, L., Rui, H. \& Attramadal, A. (1985) Oestrogen receptors in stromal and epithelial fractions of the rat ventral prostate. Archs Androl. 15, 143-151.

Rose, R.M., Gordan, T.P. \& Berstein, I.S. (1972) Plasma testosterone levels in the male rhesus: influences of sexual and social stimuli. Science, N.Y. 178, 643-645.

Rui, H., Gerhardt, P., Mevåg, B., Thomassen, Y. \& Purvis, K. (1984) Seminal plasma characteristics during frequent ejaculation. Int. J. Androl. 7, 119-128.

Rui, H., Gordeladze, J.O., Mevåg, B., Haug, E., Brekke, I. \& Purvis, K. (1985a) Circadian rhythms in accessory sex gland function in the male rat. Urol. int. 40, 331-336.

Rui, H., Haug, E., Mevåg, B., Thomassen, Y. \& Purvis, K. (1985b) Short-term effects of prolactin on prostatic function in rats with lisuride-induced hypoprolactinaemia. J. Reprod. Fert. 75, 421-432.

Rui, H., Brekke, I., Morkås, L. \& Purvis, K. (1986) Androgen interaction with the polyamine system of the rat prostatic complex. Molec. cell. Endocr. (in press).

Russell, O.H. (1980) Ornithine decarboxylase as a biological and pharmacological tool. Pharmacology 20, $117-129$.

Saginor, M. \& Horton, R. (1968) Reflex release of gonadotrophin and increased plasma testosterone concentration in male rabbits during copulation. Endocrinology 82, 627-630.

Williams-Ashman, H.G. \& Lockwood, D.H. (1970) Role of polyamines in reproductive physiology and sex hormone action. Ann. N.Y. Acad. Sci. 171, 882-894.

Wilson, J.D. (1980) The pathogenesis of benign prostatic hyperplasia. Am. J. Med. 68, 745-755.

Received 20 August 1985 